\title{
ХИПОКРИТСКИ КОН ХИПОКРАТ
}

\section{Кратка содржина}

Во османлиска Македонија силно се чувствувал недостатокот од професионален медичински кадар. Со исклучок на турските воени екими ито ги опслужувале месните гарнизони, во македонските градови во втората половина на XIX век работел занемарлив број христијански лекари. Присуството, пак, на лекари во селата било вистинска реткост. Ваквите околности придонеле лекарите да ги заземат повисоките скалила на опитествената пирамида. Странските пропаганди биле свесни за перспективите што би се отвориле доколку успеат да обезбедат патронажа врз македонските медииинари. Влијанието ито го нудела лекарската професија им овозможсувало на лекарите успешно да агитираат кај македонскиот народ во полза на свочте работодавии. Оттука, во последната деченија на XIX век, министерствата за надворешни работи на балканските држави не штеделе средства за финансирање на своја лекарска фаланга во Македонија. Прва жртва во оваа борба за освојување на следбеници било токму македонското христијанско население, кое за да ги задоволи своите основни хумани и здравствени потреби било принудено да прави компромиси со себе и со својата национална свест.

Во долните редови ке го разгледаме начинот на кој бугарската и другите пропаганди на балканските држави ја користеле медиџината за да ги остварат свочте завојувачки планови во Македонија. Притоа, со компаративна анализа ке ја тестираме тезата на бугарската историографија дека грчките, српските и романските лекари биле пропагатори, а дејноста на бугарските лекари била „, чисто хумана и насочена кон лекување на болното бугарско население."

клучни зборови: ЛЕКАРИ, ПРОПАГАНДА, МАКЕДОНИЈА, БУГАРИЈА

Кога ќе влезам во некоја куќа, тоа ќе биде само за да лекувам некој болен.

Дел од Хипократовата заклетва

Ваша задача е да ја будите националната свест кај Бугаринот секогаш кога ќе имате контакт со него.

Заповед од Егзархијата до бугарските лекари во Македонија

1. Како резултат на грчко-турскиот граничен договор од 1881 година и стабилизирањето на односите меѓу Цариград и Атина, дошло до зацврстување и 
проширување на грчките позиции во Македонија. Во овој контекст, едно од средствата со коишто атинските државници во почетокот на 1880-тите години планирале да освојат терен на сметка на останатите претенденти за Македонија било испраќањето грчки лекари кои требале да ја зацврстат или „повторно да ја разбудат“ грчката свест кај македонското население. ' Затоа, во 1883 година, грчкото Министерство за надворешни работи го сондирало мислењето на своите конзули во Македонија во врска со реалната потреба од испраќање грчки лекари во македонските вилаети. Грчките конзули биле подобро запознаени со фактичката состојба на теренот и не се согласиле со размислувањата на атинските политичари за испраќање лекари со грчко државјанство во Македонија. Имено, недостатокот на квалификуван медицински кадар од егзархиските редови им овозможувал на патријаршиските лекари своевиден монопол при лекувањето на христијанското население во Македонија. Притоа, сите општински болници се наоѓале во грчки раце и биле финансирани од патријаршиските општини.

Од друга страна, како што истакнал грчкиот конзул во Солун, Петрос Логотетис, испраќањето грчки лекари во Македонија би предизвикало жестока реакција од страна на османлиските власти. Според конзулот, доколку овие лекари не биле османлиски државјани, тие би биле протерани од властите, а пак доколку биле османлиски поданици коишто се финансирани од грчкото кралство, тогаш тие би биле уапсени и затворени. Затоа, Логотетис претпочитал да им се даде предност на лекарите од Македонија, кои и до 1883 година успешно ја прикривале својата „национална активност“" од власта и работеле во корист на грчката пропаганда. ${ }^{2}$

Грчкото Министерство за надворешни работи (МНР) го прифатило мислењето на грчкиот конзул и до средината на 1890-тите години, грчките лекари во трите македонски вилаети биле османлиски поданици, коишто биле финансирани од локалните патријаршиски општини и инструирани да соработуваат со патријаршиските свештеници и учители во средината во која биле упатени да дејствуваат. Кон крајот на XIX век, дел од грчките лекари во Македонија биле финансирани од грчката влада, со посредство на грчките конзулати во Македонија. ${ }^{3}$

Кога се обработуваат активностите на грчките лекари во Македонија, едно од најзастапените мислења во бугарската историографија е дека тие биле воспитаници на медицинскиот факултет во Атина, со сомнителни медицински познавања. Притоа, се истакнува дека нивна првостепена задача била „елинизација на бугарското население“, а медицинските познавања биле само средство за остварување на целта. ${ }^{4}$

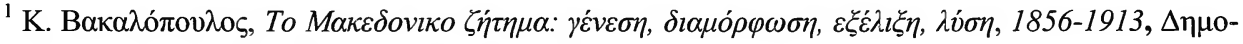

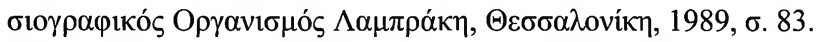

${ }^{2}$ Ibid.

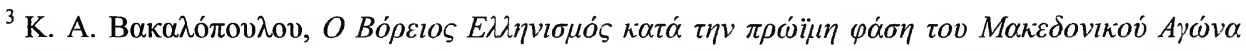

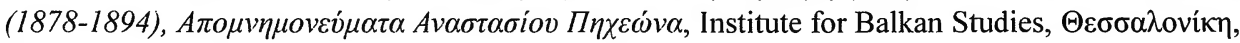
1983, б. 47.

${ }^{4}$ И. Галчев, Здравно-сочиалната дейност на Българската екзархия в Македония и Тракия (1870-1913), Юруков, София, 1994, с. 94. 
Што се однесува до првата теза, со премолчување или искривување на фактите, бугарските истражувачи на оваа проблематика се обидуваат да остават впечаток дека Бугарија се грижела за здравјето на своите „сонародници“ во Македонија и затоа таму ги испраќала своите најдобри лекари, образовани во најелитните медицински центри во Западна Европа, додека Грција претпочитала да испраќа луѓе кои биле подобри пропагандисти отколку медицинари. Ова, секако, не соодветствува со вистината, бидејќи голем број од грчките лекари во Македонија дипломирале и специјализирале во Париз, Виена, Берлин и Грац, ${ }^{5}$ и поради својата стручност биле уважени и ценети од османлиските власти. Втората теза наоѓ⿱ поткрепа и во изворната документација, која потврдува дека грчките лекари честопати ја користеле својата функција како параван за извршување на пропагандистички дејства. ${ }^{6}$

Хипократовата заклетва добила дополнителен удар за време на т.н. грчка македонска борба, кога грчките лекари целосно се ставиле во функција на грчката големодржавна политика. Во периодот 1904-1908 година, покрај тоа што ги лекувале ранетите андарти, грчките лекари, во улога на интелектуална елита на грчката пропаганда во Македонија, извршувале редица функции што немале никаква допирна точка со медицината. Долгогодишниот грчки лекар во Клисура, Јоанис Аргиропулос, станал еден од главните соработници на конзулот Ламброс Коромилас, и заедно со костурскиот митрополит Германос Каравангелис застанал на чело на борбата за враќње на костурските егзархиски села под капата на Патријаршијата. Д-р Анастасиос Хрисафис од Сер раководел со преносот на оружје од Орфанскиот Залив кон Сер и бил задолжен за снабдување со оружје на грчките андартски чети во Источна Македонија. Истата функција во Западна Македонија ја имал д-р Јанулис Sимас, кој работел како грчки лекар во Хрупишта. Хирургот Ставрос Налис бил еден од основачите на грчкиот револуционерен комитет во Би-

${ }^{5}$ Д-р Димитриос Занас, кој работел како грчки лекар во Солун, завршил медицински факултет во Берлин. Грчкиот лекар во Сер, Анастасиос Хрисафис, дипломирал на медицинскиот факултет во Виена. Докторите Михаил Типадис и Менелаос Батринос, кои работеле како грчки лекари во Хрупишта и Костур, специјализирале во Виена и Грац, а д-р Димитриос Ризос и д-р Дукас Сахинис специјализирале во Париз и работеле како грчки лекари во Струмица, Во-

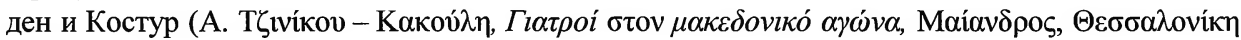

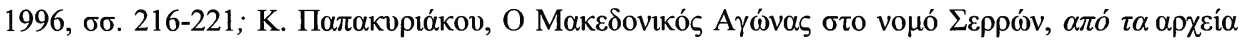

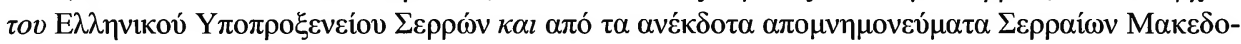

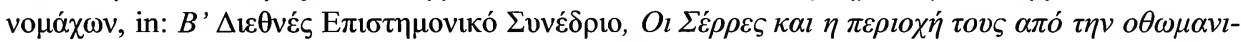

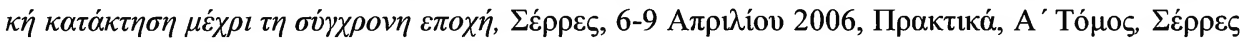
2013, б. 52).

6 Таков бил случајот со д-р Димитриос Кивернидис, кој работел како околиски лекар во Гевгелија, и д-р Ангелакис Сакелариос во Гуменџе. Тие, и покрај тоа што речиси и немале пациенти, стоеле на чело на грчките партии во односните места и го попречувале ширењето на револуционерната агитација меѓу патријаршиското население. Кивернидис и Сакелариос биле финансирани од грчката влада и биле во постојан контакт со патријаршиските митрополити и грчкиот конзул во Солун (Види: В. Ѓор́́иев, Апостол Петков Терзиев Кралот на Блатото, ДАРМ - Македоника литера, Скопје, 2013, стр. 48, 52). 
тола и имал задача да врбува андарти од Битола и Битолско. Доктор Христодулос Пердикарис бил лидер на грчкиот револуционерен комитет во Негуш, неговиот колега д-р Димитриос Ризос ја координирал грчката вооружена пропаганда во Воден итн. ${ }^{7}$

Во грчки раце се наоѓале и најголемиот број аптеки во Македонија. Овие аптеки биле подобро снабдени со лекарства од сите останати дрогерии во Македонија. Користејќ ја привилегираната положба, грчките аптекари ја злоупотребувале потребата на населението од лекарства за да агитираат во полза на грцизмот, а понекогаш преземале и мерки кои целосно се коселе со благородноста на нивната професија. Во тој контекст, индикативно е недатираното писмо кое егзархиската црковна општина во Хрупишта го испратила до бугарскиот егзарх Јосиф I, во кое членовите на општината се жалат дека грчките духовни водачи во Костур им заповедале на аптекарите да ги трујат егзархистите. Притоа, се додава дека десетина егзархисти веќе починале како последица на лекарствата купени во локалните грчки аптеки. ${ }^{8}$

2. Прв кој ја разбрал важната улога што би можел да ја одигра медицинскиот кадар за српската пропаганда во Македонија бил српскиот конзул во Скопje, Владимир Кариќ. Со оглед на тоа што ниту бесплатното школување на Македонци во Србија, ниту испраќаето големи пратки учебници, ниту, пак, давањето парична помош за училиштата не обезбедиле позначаен број српски приврзаници во Македонија, српските пропагандни фактори биле принудени да бараат алтернативни решенија за унапредување на пропагандата. Така, во почетокот на 1889 година, во функција на раководител на Одделението за училишта и цркви надвор од Србија при српското Министерство за образование, Владимир Кариќ ја лансирал идејата за организирање српски колонии во македонските градови. Кога кон крајот на истата година станал српски конзул во Скопје, Кариќ започнал да ја спроведува својата замисла на дело. Во контекст на неговиот план за унапредување на српската пропаганда преку дејствување на српски колонисти, било и пристигнувањето на првите српски лекари во Македонија. На почетокот на 1892 година, во Скопје бил доведен д-р Михаило Шушкаловиќ. Во мај 1895 година, за лекар во интернатот при српската гимназија во Скопје бил назначен д-р Чедомир Ѓорѓевиќ, кој во 1897 година бил заменет од д-р Слободан Рибникар. Во летото 1895 година, од Србија во Битола била испратена акушерката Марија Јунгиќ. Во 1896 година,

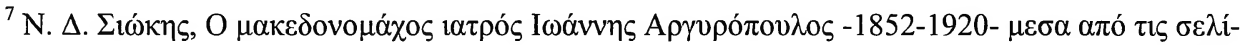

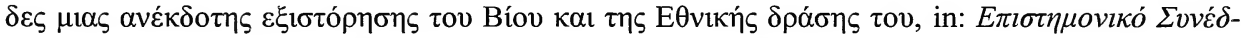

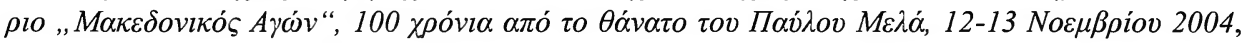

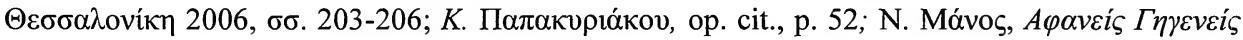

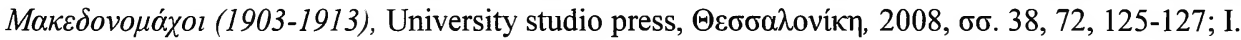

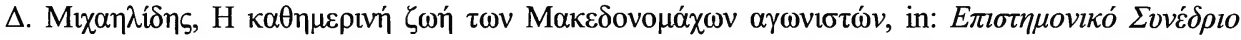

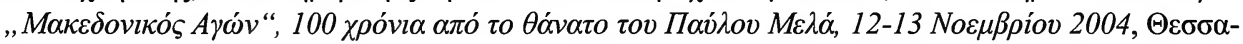

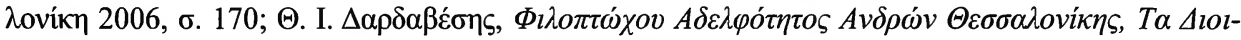

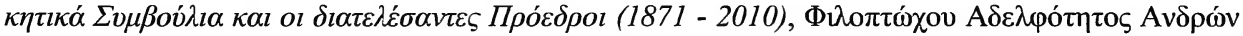

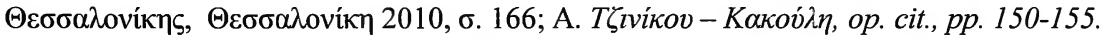

${ }^{8}$ И. Галчев, Здравно-сочиалната дейност..., с. 18.
} 
нишлијата Ѓорѓe Крстиќ ја отворил првата српска аптека во Скопје. ${ }^{9}$ Сите тие, без исклучок, се наоѓале на платниот список на српското МНР. Притоа, нивна главна должност била бесплатно да им укажуваат помош на сите сиромашни приврзаници на српската пропаганда, и особено на приврзаниците на грчката и на бугарската пропаганда кои би побарале медицинска помош од српските лекари. ${ }^{10}$

Приливот на српски лекари значително се засилил по Грчко-турската војна во 1897 година и отстапките со кои османлиската влада ја наградила српската неутралност во војната. Во писмо од 27 октомври 1897 година, бугарскиот трговски агент во Солун, Атанас Шопов, го информира МНР во Софија дека српската пропаганда определила десет лекари кои требало да бидат испратени во Македонија со пропагандна цел. Шопов истакнува дека еден од десетте лекари веќе ја зазел својата позиција во Солун. ${ }^{11}$ Притоа, овие лекари биле распоредени на стратегиски важни места за српската пропаганда, како што се Скопје, Дебар, Кичево, Куманово, Гевгелија, Прилеп, Солун итн. и тие имале директна наредба бесплатно да го лекуваат егзархиското население кое би побарало помош од нив. За разлика од првите српски лекари во Македонија, кои потекнувале од Србија, поголем дел од српскиот медицински персонал во првата деценија од XX век бил со македонско потекло. ${ }^{12}$

3. Во последната деценија на XIX век и Романија сфатила дека медицината била моќно оружје на пропагандното бојно поле. Свесна за начинот на којшто функционирале народите во Македонија, романската пропаганда ги стимулирала влашките лекари да останат во родната земја и да отворат свои ординации. Затоа, во 1893 година романската влада започнала да го стипендира школувањето на неколку Власи на медицинскиот факултет во Цариград, со обврска, по завршувањето на студиите, да се вратат во Македонија и да работат како романски лекари. Во 1900 година дипломирала првата класа романски стипендијанти, кои веднаш биле распоредени низ болниците во Македонија. Д-р Пандели Машу се вработил како романски лекар во велешката болница, а лекарите Јани Бараку и Симу Бербери отвориле романски ординации во Битола и во Костур. Истата година, романската пропаганда се обидела да основа романска болница во Солун, но набргу следувало намалување на

\footnotetext{
9 Љ. Доклестик, Српско-македонските односи во 19 век, НИП Нова Македонија, Скопје, 1973, стр. 314-315

${ }^{10}$ Ibid., cтр. 314-5.

11 ДАРМ, фонд Бугарско трговско агентство - Битола, мф. 4297, ф.331, оп.1, ае.16, с.18, 19, 21, 24, Солун, 27.10.1897.

${ }^{12}$ Сѐ до Балканските војни, дејноста на српските лекари претставувала трн во окото на дејците на бугарската пропаганда во Македонија. Така, Дебарската егзархиска митрополија редовно се жали кај Егзархијата за дејноста на српскиот лекар во Кичево и на галичанецот д-р Исо Аџиевски во Дебар, кои давале бесплатна медицинска помош и перманентно агитирале кај „бугарското население“. Во писмо од Дебарската митрополија до Егзархијата од 14 август 1908 година, се истакнува дека српскиот лекар „оди по нашите бугарски куќи и по бугарските села и, покрај докторлакот, проповеда и српски идеи на коишто веруваат слабите и малодушни луѓе... а тоа не е во интерес на бугарската црква“ (ДАРМ, фонд Дебарско-кичевска митрополија 1897-1918, кут. 7, о.п 1, а.е 396, л. 17).
} 
романските буџетски средства наменети за пропагандата во Македонија, со што и идејата за основање романска болница во Солун останала нереализирана. Во секој случај, во споредба со малиот број романски приврзаници меѓу влашкото население во Македонија, романската пропаганда располагала со завиден број лекари и аптекари. Само во Битола „Романците“ имале тројца лекари, од кои еден бил хирург, а во неколку македонски градови функщионирале и романски аптеки. За да се заобиколат бирократските пречки, овие романски лекари биле пријавувани како училишни лекари во романските училишта и платата ја примале од романското Министерство за образование и вероисповед. Притоа, тие биле задолжени да му укажуваат бесплатна медицинска помош на сиромашното пророманско население и да ја разбудат романската национална свест кај Власите. ${ }^{13}$

4.1. Во 1880 година Егзархијата го назначила Кузман Шапкарев за учител во Солун. За време на неговиот престој во вилаетскиот центар, Шапкарев развил жива кореспонденција со архимандритот Методи Кусев, кого постојано го известувал за сите важни настани во Македонија. Една од темите за коишто Шапкарев пишува во своите писма била и дејноста на грчките лекари и аптекари и нивното огромно влијание кај османлиските власти и егзархиското население. ${ }^{14}$ Во обид да им се парира на грчките лекари, тој дава конкретен предлог до Егзархијата да назначи свои лекари во Македонија. Негов прв предлог е д-р Иван Врањат од Воденско, кого Шапкарев го предлага за егзархиски лекар во Струмица. ${ }^{15}$ Кусев ја избегнал одговорноста, истакнувајќ дека во отсуство на егзархот тој не можел да одлучува за толку важни прашања. Бурниот развој на бугарската просвета во Македонија во 1880-тите години, сепак, резултирал со посериозен пристап кон предлогот на К. Шапкарев. До 1884 година, во Македонија функционирале неколку бугарски гимназии, педагошки училишта и духовни семинарии. Во рамките на овие установи биле отворени и пансиони, во кои на стипендијантите и на останатите пансионери им биле обезбедени легла, храна, греење и облека. Силната концентрација на ученици во пансионите, како и релативно нехигиенските услови во нив, го поставиле прашањето за ангажирање медицински лица кои би се грижеле за здравјето на пансионерите. Затоа, во егзархискиот буџет за 1884/85 година прв пат биле одделени материјални средства за училишни лекари. ${ }^{16}$ Меѓутоа, недостатокот на квалифи-

${ }^{13}$ Н. Минов, Влашкото прашање и романската пропаганда во Македонија (1860-1903), Арс либрис, Скопје, 2013, стр. 319-20.

${ }^{14}$ Шапкарев вели: „Тие назначија лекари од Атина, со огромни плати, и ги испратија во македонските градови со определена двојна цел: 1) да го лечат турското население за да го привлечат кон себе... и во улога на градски лекари да се втурнат меѓу управувачките и влијателни кругови; 2) како градски лекари, наместо да лечат, со мајсторски отрови да ги истребуваат првенците и поспособните Бугари - интелигентните предводници на народното дело“ (К. Шапкарев, За възраждането на българщината в Македония, Неиздадени записки и писма, Съставителство и редакция: Илия Тодоров, Николай Жечев, Предговор: Петър Динеков, Български Писател, София, 1984, с. 469).

${ }^{15}$ И. Галчев, За бъднините и делата български (Непубликувани писма на К. Шапкарев), Пиринско дело, 40/ 252, София, 1984, с. 4.

${ }^{16}$ И. Галчев, Здравно-сочиалната дейност..., с. 143. 
куван медицински кадар во егзархиските редови ги принудил егзархиските водачи да ја разгледаат понудата на лекари од останатите милети. Така, прв и долгогодишен лекар во пансионот при Женската солунска гимназија бил власизираниот Албанец д-р Михаил Христович, кој во својата куќа отворил и болница во која се лекувало малобројното егзархиско население во Солун. ${ }^{17}$

4.2. Доколку главната цел на лекарите кои биле субвенционирани од Бугарската егзархија била „чисто хумана - лекување на болното бугарско население“, 18 тогаш ангажирањето лекари од патријаршиските средини воопшто не би претставувало проблем. Но, се чини дека лекувањето „болни Бугари“ не било доволно, па егзархот Јосиф одбил да ги назначи Албанецот д-р Васил Георгијади за бугарски лекар во Емборе и патријаршистот д-р Христо Шанов за егзархиски лекар во Костур. Истовремено, тој испратил писмо до световните власти во Софија дека е „свесен за големата потреба од бугарски лекари во Македонија и дека непрекинато се бараат погодни кандидати, но тие не треба да бидат туѓинци“. ${ }^{19}$ Тоа дека „лечењето болни Бугари“ не било примарна цел при ангажирањето лекари се потврдува од уште едно писмо на бугарскиот егзарх, во кое истакнува дека „наполно ја осознаваме потребата од бугарски лекари во Македонија и нашето гледиште за тоа прашање секогаш било дека задоволувањето на таа потреба е толку итно од гледиште на општественото здравје колку, ако не и повеќе, од културнонационално гледиште“. ${ }^{20}$ Во овој контекст, Егзархијата го моли МНР на Бугарија да ги покани македонските лекари од Кнежеството да се вратат во своите родни места.

Во потрага по начини за прибирање медицински кадри, се родила идејата да се даваат стипендии за учениците од бугарските гимназии во Македонија, за тие да изучуваат медицина и фармација во Цариград, Бејрут и во европските центри. Така, за учебната 1889/90 година, од утврдениот буџет на Егзархијата од 565, 094 лева, 10,000 лева биле предвидени за стипендисти кои би учеле медицински и правен факултет во горенаведените центри. Според наредбата од бугарскиот министер за надворешни работи, Георги Странски, студентите што ке ги изучат овие науки биле задолжени да иे служат на татковината. ${ }^{21}$ Во подоцнежните проект-буџети, Егзархијата продолжила во ставката „разни расходи“ да внесува суми за различни стипендии. И бугарската влада се согласила секоја година да испраќа по 10 стипендисти во американското медицинско и фармацевтско училиште во Бејрут,

\footnotetext{
${ }^{17}$ Царевна Миладинова погрешно ја нарекува оваа болница „Бугарска болница“. Станува збор за приватна клиника во која најчесто се лечело македонското егзархиско и влашкото романизирано население (Ц. Миладинова-Алексиева, Епоха, земя и хора, Съставителство, коментар и бележки Елисавета Миладинова, Издателство на Отечествения фронт, София, 1985, стр. 118-9).

${ }^{18}$ И. Галчев, Здравно-сочиалната дейност..., с. 25.

${ }^{19}$ В. Георгиев и С. Трифонов, Екзарх български Йосиф I, Писма и доклади, Клуб 90, София, 1994, стр. 154-5.

${ }^{20}$ И. Галчев, Здравно-социалната дейност..., с. 31.

${ }^{21}$ Ibid., p. 34.
} 
кои по дипломирањето, биле должни да се вратат во своите родни места и да работат на струката. На тој начин, Бугарија сметала дека по 10 години во секој македонски град и поголемо село ке има бугарски лекар. Притоа, биле посочени шест услови што требало да ги исполнат стипендистите - да ја завршат полната гимназија со добар успех и добро поведение; да не се повозрасни од 21 година; да се здрави; да се родени во некој од македонските вилаети; да припаѓаат на чисто бугарски егзархиски семејства и родителите да им живеат во Македонија. ${ }^{22}$ Очигледно, за да ја исполнат културно-националната задача за која зборува бугарскиот егзарх, идните лекари требало да бидат млади и локални бугарски воспитаници, кои преку егзархиските просветни институции веќе биле обликувани по бугарски терк.

4.3. Здравствено-социјалната дејност на Бугарската егзархија била раководена од нејзиниот Училиштен оддел. Лекарите кои ѝ биле потчинети на Егзархијата биле поделени во две основни групи: училишни и реонски. Вообичаена практика било училишните лекари да бидат и пансионски. Сепак, оваа поделба била повеќе теоретска отколку практична. Малиот број егзархиски медицински кадар во Македонија им налагал на лекарите истовремено да ги исполнуваат и двете должности. Поголемиот број егзархиски лекари работеле приватно, во сопствени ординации, но како егзархиски лекари тие биле должни да ги исполнуваат своите задолженија кон Егзархијата. Затоа, нивната плата и задолженијата биле определени со заповед од Бугарската егзархија. Така, секој лекар назначен од Училишниот оддел на Егзархијата бил должен: „1) да одговори на секоја покана од управникот на епархијата за давање медицинска помош во вонредни случаи, за што би му биле исплатени патни трошоци; 2) најмалку два пати годишно да го обиколува целиот регион без патни трошоци и да му дава бесплатна медицинска помош на секој сиромав Бугарин; 3) по секоја обиколка, да достави медицински извештај до Егзархијата, во кој ќе ја извести за состојбата во поверениот реон; и 4) да ја буди националната свест кај Бугаринот во (назив на градот) и околината, секогаш кога ке има контакт со него“. ${ }^{23}$ Не ни е познато дали Егзархијата била запознаена со делот од Хипократовата заклетва во кој лекарите се обврзуваат дека нивната единствена дејност при влегувањето во нечиј дом ќе биде лекување на болните, но нејзината четврта заповед до егзархиските лекари јасно покажува дека таа не се согласува со Хипократ. Од друга страна, со оглед на фактот што овие задолженија воопшто не се промениле сѐ до крајот на османлиската доминација во Македонија, се чини дека и по повеќедецениско дејствување на егзархиските црковно-просветни институции, националната свест кај „Бугаринот“ во Македонија не била разбудена ни до Балканските војни ${ }^{24}$ или, пак, воопшто и не пос-

${ }^{22}$ Ibid.

${ }^{23}$ Ibid., p. 36.

${ }^{24}$ При назначувањето егзархиски лекар во Драма, на 6 октомври 1911 година д-р Михаил Крстев добил задолжение да ја разбуди националната свест на Бугаринот во Драма и околината. Само неколку дена претходно, Егзархијата го назначила д-р Кирил Георгиев за реонски лекар во Куманово. Притоа, во писмо од 29 септември 1911 година, лекарот е известен дека „Егзархијата верува дека тој со полно сознание ќе го исполни својот долг кон на- 
тоела во обликот во којшто бугарските институции сакале да ја претстават пред европската јавност.

Напорите на Бугарската егзархија да обучи и да привлече образован медицински кадар од егзархиските средини не давале плод сѐ до крајот на XIX век. До 1897 година, единствените егзархиски лекари кои биле образовани во западните медицински центри биле братучедите Христо и Божирад Татарчеви, кои студирале на медицинските факултети во Цирих и Берлин, и охриѓанецот Ангел Робев, кој дипломирал на медицинскиот факултет во Лајпциг. ${ }^{25}$

Околностите налагале во играта да се вклучат фактори со поголема политичка и финансиска моќ.

4.4. Како резултат на неутралноста за време на Грчко-турската војна од 1897 година, Бугарија се стекнала со нови бенефиции во Македонија. Истата година Кнежеството добило три митрополитски берати за Струмичката, Дебарската и Битолската епархија и право да отвори трговски агентства во Солун, Битола и во Скопје, а во 1898 година и во Сер. Српската неутралност за време на војната помеѓу Османлиската Империја и Грција, исто така, била наградена со право за отворање српски училишта во Битолскиот и во Солунскиот вилает, како и со назначување на Фирмилијан за администратор на Скопската патријаршиска митрополиja. Бугарската пропаганда набрзо ги почувствувала српските придобивки на своја кожа. На десет места во Македонија биле испратени српски лекари, кои му овозможувале бесплатна медицинска помош на егзархиското население. Така, во 1897 година бил испратен српски лекар во Прилеп, кој поради своите услуги веднаш се стекнал со извесно влијание во градот. Набргу потоа било отворено и српско училиште во Прилеп, кое за краток период успеало да оттргне околу 250 ученици од локалните бугарски училишта. ${ }^{26}$ Со цел да ја унапреди својата пропаганда, но и да им парира на српските ривали во Македонија и да го заземе теренот што привремено бил препуштен од поразеното грчко кралство, бугарскиот премиер Константин Стоилов започнал подолга расписка со своите трговски агенти во македонските вилаети. Дискусијата, главно, била насочена кон преговарање со ТМОРО, но дел од извештаите на трговските агенти го убедиле Стоилов дека црковно-училишната активност не била доволна за остварување на бугарските интереси во Македонија. Пресудна улога за промена во дотогашната политика одиграле неколку извештаи на бугарскиот трговски агент во Скопје, Димитар Ризов. Кон кра-

родот, не само како лекар, туку и како Бугарин родољуб, кој никогаш не треба да го испушти случајот да ја буди националната свест кај нашиот народ“ (Ibid., pp. 36, 121).

${ }^{25}$ Христо Татарчев бил назначен за училиштен лекар во Солун, а Божирад за лекар на 4 машки и 3 женски пансиони во Скопје. По само една година, во 1893, Божирад Татарчев го напуштил Скопје и заминал на специјализација во Париз. Д-р Ангел Робев бил назначен за училиштен и пансионски лекар во Битола, каде што ги предавал предметите хитиена и популарна медищина.

${ }^{26}$ Й. Шопов, Българската екзархия и националноосвободителното движение в Македония и Одринско 1878-1912, Известия на Църковноисторически и архивен институт, том 3, София 1985 , с. 335. 
јот на 1897 година, Ризов го поставил прашањето за привршување на борбата за приложување на ферманот од 1870 година, по што го повикал кабинетот на Стоилов веднаш да открие филијали на бугарската Народна банка во Македонија, да го форсира прашањето за изградба на железничка линија помеѓу Ќустендил и Куманово, да направи драстични модификации во училишните програми за бугарските училишта во Империјата и да се испратат во Македонија квалитетни бугарски лекари, аптекари и адвокати. ${ }^{27}$ Стоилов ги одобрил барањата на својот трговски агент и ги исцртал идните насоки за дејност на неговата влада: „По добивањето на последните берати... сметам дека ферманот за уредувањето на Егзархијата е исполнет и дека црковната програма за Македонија е остварена. Мислам дека е време да се направи еден чекор напред во нашата македонска политика... Тој чекор треба да биде во двојна насока: а) преку добивање possession de facto (сопственост на дело, б.н.) на Македонија - трговски агентства, поврзување (на) железниците, банките, лекари, учители и сето останато што може да потпадне под категоријата на prise de possession (стекнување сопственост, б.н.)...“. ${ }^{28}$

Во 1898 година бил направен обид за да се разбере какви резултати би се постигнале од дејноста на бугарски лекари во Македонија. Во доверливо писмо од 2 јуни 1898 година до бугарскиот премиер и министер за надворешни работи, Стоилов, бугарскиот трговски агент во Солун, Атанас Шопов, пишува дека се сретнал со д-р Владимир Руменов, кој патувал кон Скопје, и му се доверил на бугарскиот агент дека токму тој бил експериментот. Доколку Руменов се покажел како корисен, тогаш прашањето за испраќање други лекари во Македонија би било конечно решено. Доктор Руменов бил назначен за лекар во женското училиште и во педагошките училишта во Скопје директно од Военото министерство. За неговата дејност бугарскиот трговски агент во Скопје се изразува со суперлативи: „Со својата неуморна дејност во кругот на својата специјалност, како и со својот патриотизам, д-р Руменов наполно ги оправда целите и очекувањата за коишто е испратен во тој крај на Македонија. Подготвен е во секое време, дење и ноќе, при првиот повик да им укаже медицинска помош на оние на кои таа им е потребна... и не избегна во ниеден случај да биде корисен за... бугарското црковно-училишно дело и, воопшто, за бугарските општествени интереси““. ${ }^{29}$ И Шопов сметал дека биле постигнати добри резултати од дејноста на д-р Руменов и му препорачува на Кнежеството да испрати супсидирани лекари и во другите македонски градови. Солунскиот трговски агент истакнал и дека испраќањето бугарски лекари во Македонија е „моќно средство, силен лост за поттикнување на успехот на нашето дело... Можеби и нема друга професија којашто толку успешно и толку сигурно ќе влијае врз населението како што е лекарската“. Затоа тој препорачува да се побрза со испраќање бугарски лекари, особено во градовите Воден, Ениџе Вардар, Гевгелија, Велес, Неврокоп, Дојран и Кукуш. ${ }^{30}$

${ }^{27}$ Н. Гацевъ, Солунската българска търговска гимназия, in: сб. Солунъ, София 1934, с. 295.

${ }^{28}$ В. Божинов, Българската просвета в Македония и Одринска Тракия, 1878-1913, БАН, София, 1982, стр. 120-1.

${ }^{29}$ И. Галчев, Здравно-социиалната дейност..., стр. 102-3.

${ }^{30}$ Ibid., p. 32. 
Плодната активност на д-р Руменов ја убедила бугарската влада во полезноста од бугарски лекари во Македонија. Низ целото Кнежевство бил направен избор на стручни и интелигентни медицински кадри и во текот на 1898 година кон македонските градови се упатила елитна единица на лекари, назначени и финансирани од бугарското МНР. Прв пристигнал прилепчанецот Јордан Јанчулев, кој со средства обезбедени од бугарското Министерство за просвета, од Егзархијата и од егзархиската општина во Прилеп, го завршил медицинскиот факултет во Лион. Доктор Јанчулев бил назначен за пансионски лекар во бугарската машка егзархија во Битола. ${ }^{31}$ Веднаш по него за лекар во Сер бил назначен уште еден прилепчанец, д-р Јордан Митров, кој само неколку месеци претходно завршил медицински факултет во Киев. Третиот назначен лекар бил Милан Братов од Стара Загора, кој штотуку дипломирал на медицинскиот факултет во Нанси и веднаш бил назначен за бугарски лекар во Воден, каде што следната година отворил и аптека. ${ }^{32}$ Заедно со тројцата лекари, во Македонија пристигнала и акушерката Николина Гаврикова, која МНР ја назначило во Скопје. ${ }^{33}$ Задолженијата на овие лекари биле речиси исти со оние на медицинските лица што ги назначувала Бугарската егзархија. Единствената разлика се состоела во тоа што тие поднесувале извештај за својата работа во МНР на Бугарија, или кај бугарските трговски агенти.

Може да се забележи дека горенаведениот медицински персонал бил упатен во локалитети во кои патријаршиските позиции биле посилни од оние на Егзархијата или, пак, како што е случајот со Скопје, во места кон кои српската пропаганда покажувала силни претензии. Во овој контекст, симптоматичен е одговорот од бугарскиот премиер и министер за надворешни работи, Димитар Греков, кој на барањето од битолскиот митрополит Григориј и од егзархиската црковна општина во Прилеп да се премести д-р Митров од Сер во Прилеп, одговорил дека не може да го исполни барањето, бидејќи Министерството не располагало со доволно средства, а оние што ги имало ги наменувало за „назначување лекари каде што бугарското население е малобројно и не може самото да се заштити од туѓите пропаганди“. ${ }^{34}$ Оваа изјава од еден бугарски премиер целосно ја депласира тезата на бугарската историографија дека целта на бугарските лекари во Македонија била од чисто хумана природа. Од друга страна, зборовите на Греков претставуваат и своевиден парадокс, бидејќи покрај тоа што ѝ противречат на тезата за хуманата активност на бугарските лекари, оставаат впечаток дека на прилепчани не им бил потребен лекар, затоа што како егзархисти веќе биле придобиени за бугарската кауза! За иронијата да биде поголема, двајца од тројцата лекари субвенционирани од бугарското МНР биле од Прилеп.

4.5. Интервенцијата на кнежевското МНР ја поставила бугарската здравствено-пропагандна дејност на поцврста основа. Меѓутоа, безбедноста во Кнеже-

31 ДАРМ, фонд Бугарско трговско агентство - Битола, мф. 4297, ф.331, оп.1, ае.35, с.1-31, Битола, 15.11.1898.

${ }^{32}$ И. Галчев, Здравно-сочиалната дейност..., стр. 113, 122.

33 Ibid., p. 37.

${ }^{34}$ Ibid., p. 123. 
ството Бугарија и стравот за сопствениот живот во османлиските провинции и во иднина претставувале пречка при ангажирањето медицински кадар. Затоа, Егзархијата и владата во Софија биле принудени да бараат алтернативни решенија за унапредување на својата „хумана“ дејност во Македонија. ${ }^{35}$ Во 1899 година егзархот Јосиф I издал наредба во гимназиите и во педагошките училишта во Солун, Битола, Сер и во Скопје да се изучуваат предметите антропологија, хигиена и практична медицина. Целта на оваа заповед била идните учители да се оспособат за давање медицинска помош, со што делумно би се намалила големата потреба од лекари. Мошне сериозно се размислувало и за отворање бугарски клиники во Битола, Солун и во Скопје. Бугарските министерства ги синхронизирале своите акции и започнале целонасочна активност за привлекување медицински кадри и нивно испраќање во Македонија: 1) оние лекари што работеле во Македонија, а биле на платниот список на бугарското МНР добивале двојни повисоки плати од своите колеги во Софија, и речиси тројно поголеми средства од еден директор на средно училиште. Така, додека директорот на бугарското педагошко училиште во Сер имал годишна плата од 80 турски лири, д-р Димитар Владов, како реонски лекар во Солун и училиштен лекар во Битола, добивал 235 турски лири; ${ }^{36}$ 2) Министерството за војска им го одложувала воениот рок на бугарските поданици што работеле како лекари во македонските вилаети. Во една преписка помеѓу бугарското МНР и Министерството за војска на Бугарија, МНР побарало да му се одложи воениот рок на д-р Милан Братов од Стара Загора за да може „успешно да ја заврши полезната работа за татковината во град Воден“. Министерството за војска го прифатило барањето, под услов д-р Братов да остане на служба во Македонија уште три години; ${ }^{37}$ 3) Министерството за внатрешни работи на Кнежеството, во соработка со Дирекцијата за јавно здравје, во повеќе наврати ги повикува македонските лекари што работеле во Бугарија да ги напуштат своите работни места и „да се вратат во своите родни краишта за да се предадат на професијата во служба на своите сонародници“. Притоа, Министерството за внатрешни работи остро ја прекорува Егзархијата поради пречките што им ги правела на некои македонски лекари и ја советува да овозможи поголема слобода за лекарите при нивните дејства за „постигнување на предназначената цел“. 38

Сите наведени привилегии биле последица на важната улога што им била наменета на лекарите во пропагандната војна за Македонија. За само неколку години, разните стимулации придонеле за драстично зголемување на бугарскиот медицински кадар во Македонија, со што во секое поголемо или стратегиско место

\footnotetext{
${ }^{35}$ Основен услов за слободна практика на лекарите во Османлиската Империја било одржувањето задолжителен колоквиум во Цариград, по што веќе не постоеле пречки да се занимаваат со медищинска дејност. Меѓутоа, и покрај ова, до крајот на XIX век Бугарија имала проблем во привлекувањето кадри кои би работеле како бугарски лекари во Македонија.

${ }^{36}$ И. Галчев, Българската просвета в Солунския вилает, УИ Св. Климент Охридски, София, 2005 , с. 120.

${ }^{37}$ И. Галчев, Здравно-сочиалната дейност..., с. 113.

${ }^{38}$ Ibid., p. 35.
} 
за бугарската пропаганда работел и бугарски лекар. Овие медицинари најчесто биле на платниот список на Бугарската егзархија, поретко на егзархиските црковно-училишни општини, но, понекогаш, особено кога постоеле поволни услови како Грчко-турската војна од 1897 година, или кога се заканувала опасност, каква што била територијалната поделба на сектори предвидена со Мирцштегската програма, бугарските лекари во Македонија биле врбувани и субвенционирани директно од кнежевското МНР. ${ }^{39}$ Притоа, од сите нив, без исклучок, се барало да го разбудат „бугарското национално сознание кај народот“, за што биле наградени со високи плати, а понекогаш и со генералски и полковнички чинови. ${ }^{40}$ При извршувањето на своите задачи, лекарите ја уживале поткрепата на Егзархијата, трговските агенти, и сите останати бугарски пропагандни фактори во Османлиската Империја. Во тој контекст, ќе ја истакнеме наредбата што ја упатило бугарското МНР до својот трговски агент во Сер, Стефан Кукурлиев. Откако во 1901 година МНР го назначило штипјанецот д-р Иван Голев за лекар во Сер, на Кукурлиев му било порачано целосно да соработува со лекарот и да не заборави дека преку него може да постигне одлични резултати при „сплотувањето на Бугарите и будењето на нивната национална свест“. ${ }^{41}$

Кога бугарските дипломатски претставници, црковни лица и историчари пишуваат за грчките, српските и романските лекари во Македонија, најчесто употребуван термин за да се опишат овие медицинари е терминот пропагандисти. ${ }^{42}$ Од друга страна, потребата од бугарски лекари во Македонија се објаснува со две коренито различни цели: 1) чисто хумана - да ги лекуваат болните Бугари; 2) политичка - да ги заштитуваат Бугарите од стремежите на туѓ ите пропаганди.

За да ја тестираме оваа теза, ке ги истакнеме трите главни обвинувања што им ги накалемуваат бугарските автори на другите балкански лекари: 1) тие се финансирани од нивните односни министерства; 2) агитираат кај беспомошниот

${ }^{39}$ Така, во 1904 година, како платеници на бугарското Министерство за надворешни работи, во Македонија доаѓ нова група лекари и акушерки: во Скопје се назначени д-р Никола Герасимов, д-р Петар Кушев и акушерката Рајна Чкартова, во Солун д-р Димитар Владов, во Штип д-р Иван Голев, а во Битола била испратена акушерката Константина Христова (ДАРМ, фонд Бугарско трговско агентство - Битола, мф. 4297, ф.331, оп.1, а.е.104, с.110, 1.9.1904; Исто, а.е 105, с.1-6; Исто, а.е.107, 24.5.1904).

${ }^{40}$ Д-р Владимир Руменов од Крушево достигнал до чинот санитарен генерал, д-р Петар Кушев од Велес имал чин полковник, д-р Ѓорѓи Николов од Охрид станал потполковник итн.

${ }^{41}$ И. Галчев, Здравно-сочиалната дейност..., с. 124.

${ }^{42}$ Илија Галчев тврди дека, иако не толку масивно како нивните грчки колеги, српските лекари биле пропагандисти, чија единствена цел била да го србизираат бугарското население. Во писмо од 27 јуни 1908 година до бугарскиот трговски агент во Солун, А. Шопов, егзархискиот архијерејски намесник во Воден вели дека грчките лекари биле „повеќе експлоататори и паразити отколку исцелители на човечките болести“. Во извештај од 17 ноември 1907 година, бугарскиот трговски агент во Скопје го известува своето МНР дека влашкото малцинство ги користи своите лекари за пропагандни акции (Ibid., pp. 17,21,23). 
сиромашен слој од населението; 3) ја користат медицината за да го убедат населението да се изјасни како грчко, српско или романско.

Што се однесува до првата теза, романските лекари биле финансирани од романското Министерство за образование, а српските медицинари добивале плата од Министерството за надворешни работи на Србија. Грчките лекари најчесто биле финансирани од локалните патријаршиски општини, но во одредени случаи материјалните средства ги обезбедувало грчкото Министерство за надворешни работи. Како и нивните грчки колеги, мал дел од бугарските лекари биле плаќани од локалните егзархиски црковно-училишни општини. Поголемиот број бугарски лекари се наоѓaле на платниот список на Бугарската егзархија, чиј буџет бил одобруван од бугарското Министерство за надворешни работи, а извесен број лекари биле директно назначени и финансирани од бугарското МНР.

Според втората теза, српските, грчките и романските лекари агитирале кај сиромашниот слој од населението на кое му нуделе бесплатна медицинска помош и лекови. Овој факт е потврден и од изворите. Меѓутоа, во задолженијата што ги добивале бугарските лекари од Егзархијата и од бугарското МНР, постојано било нагласувано дека една од нивните должности била бесплатно да го лекуваат сиромашното население.

Третото обвинување кон српските, грчките и романските лекари-пропагандисти се состои во тоа што тие се обидувале да ја променат националната свест на населението. Должност, пак, на бугарските лекари била да ја разбудат националната свест на своите пациенти. Во случајот, наместо знак на равенство, бугарската историографија ја користи семантиката за да се истакне некаква непостоечка разлика. Впрочем, како би можеле грчките или српските лекари да ја променат „бугарската“ национална свест на населението ако таа не е разбудена?

Оттука, можеме да резимираме дека немало разлика во практикуваниот modus operandi на бугарските, српските, грчките и романските лекари во османлиска Македонија. Затоа, доколку ја прифатиме тезата дека небугарските лекари биле пропагандисти, тогаш истиот епитет го заслужуваат и бугарските доктори. 


\section{Литература}

Божинов, В., Българската просвета в Македония и Одринска Тракия 1878-1913, БАН, София, 1982.

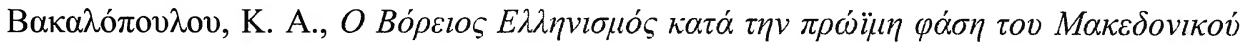

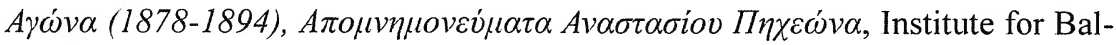

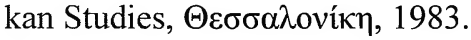

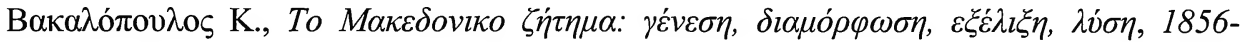

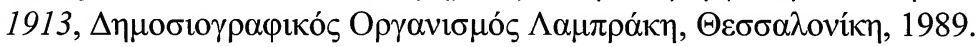

Галчев, И., Българската просвета в Солунския вилает, УИ „Св. Климент Охридски“", София, 2005.

Галчев, И., За бъднините и делата български (Непубликувани писма на К. Шапкарев), Пиринско дело, 40/252, София, 1984.

Галчев, И., Здравно-сочиалната дейност на Българската екзархия в Македония и Тракия (1870-1913), Юруков, София, 1994.

Гацевъ, Н., Солунската българска тьрговска гимназия, Сборникъ Солунъ, София 1934.

Георгиев, В. - Трифонов, С., Екзарх български Йосиф I, Писма и доклади, Клуб 90, София, 1994.

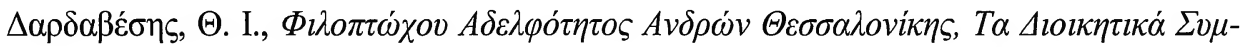

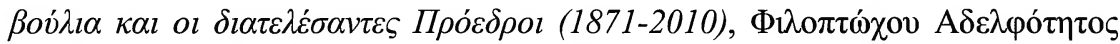

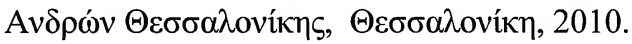

ДАРМ - фонд Дебарско-Кичевска митрополија 1897-1918

ДАРМ - фонд Бугарско трговско агентство-Битола (мф. 4297)

Доклестиќ, Љ., Српско-македонските односи во 19 век, НИП Нова Македонија, Скопје, 1973.

Ѓорѓиев, В., Апостол Петков Терзиев-Кралот на Блатото, Државен архив на Република Македонија-Македоника Литера, Скопје, 2013.

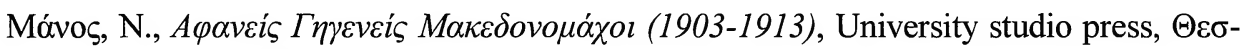

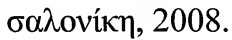

Миладинова-Алексиева, Ц., Епоха, земя и хора, Съставителство, коментар и бележки Елисавета Миладинова, Издателство на Отечествения фронт, София, 1985.

Минов, Н., Влашкото прашање и романската пропаганда во Македонија (18601903), Арс Либрис, Скопје, 2013.

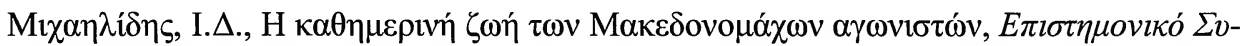

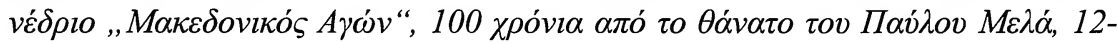

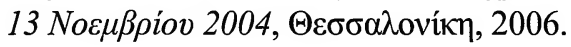

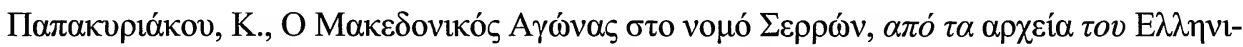

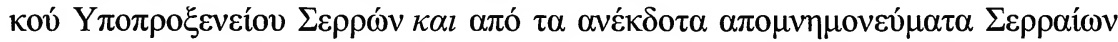




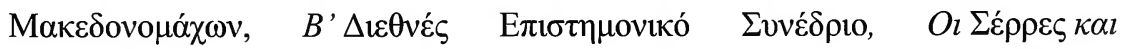

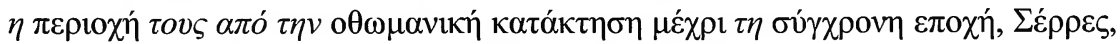

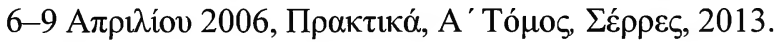

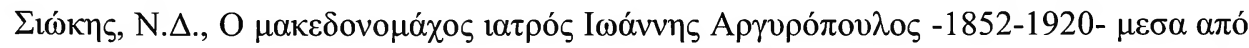

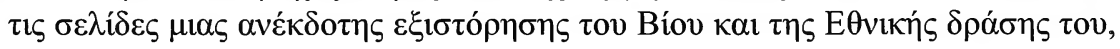

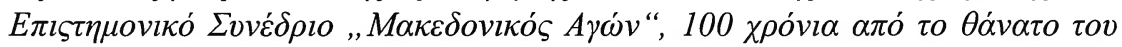

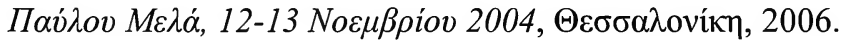

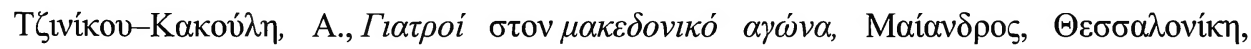
1996.

Шапкарев, К., За възраждането на българщината в Македония, Неиздадени записки и писма, Съставителство и редакция: Илия Тодоров, Николай Жечев, Предговор: Петър Динеков, Български Писател, София, 1984.

Шопов, Й., Българската екзархия и националноосвободителното движение в Македония и Одринско 1878-1912, Известия на Църковноисторически и архивен институт, том 3, София 1985. 
Nikola MINOV

\section{HYPOCRITICALLY TOWARDS HIPPOCRATES}

\section{Summary}

The lack of professional medical staff was vigorously felt in $19^{\text {th }}$ century Ottoman Macedonia. Aside from the Turkish military medics in the local garrisons, only a negligible number of Christian doctors could be found in Macedonian cities. Finding a doctor in the countryside was another rare occurrence. These circumstances placed the doctors in the highest levels of the social pyramid. The foreign diplomats and clerics were aware of the perspectives which would open up if they succeeded in their attempts to provide patronage over the medical staff in Ottoman Macedonia. Therefore, in the last decade of the $19^{\text {th }}$ century, the Ministries of foreign affairs of the Balkan states spared no resources to finance their own medical phalanx in Macedonia. The first victim in this struggle for followers was the Macedonian Christian population, which, in order to satisfy its basic human and medical needs, was forced to make compromises with itself and its national consciousness.

Here we are taking a look into the manners in which the Bulgarian propagan$d a$ and the propaganda of the other Balkan countries used the medics in order to exercise their conquering plans in Macedonia. Thereby, we will use comparative analysis to test the thesis of the Bulgarian historiography, according to which the Greek, Serbian and Romanian doctors in Ottoman Macedonia were propagandists, while the activities of the Bulgarian medics were "purely humanitarian, and aimed at healing the Bulgarian population".

Keywords: DOCTORS, PROPAGANDA, MACEDONIA, BULGARIA 